\title{
AWARENESS OF FEMALE MEDICAL STUDENTS IN KING FAISAL UNIVERSITY ABOUT HAZARDS OF CARBONATED SOFT DRINKS
}

\author{
Community Medicine \\ Sarah Zakaria \\ Alghadeer \\ Medical Intern, King Fasil University
}

\section{ABSTRACT}

BACKGROUND: carbonated drinks are composed of co2, phosphoric acid, sugars, coloring and flavoring agents and caffeine. Carbonated drinks cause serious complications like teeth decay, osteoporosis, obesity and type 2 diabetes.

The aim of the study is to assess the awareness about the hazards of carbonated drinks among the medical students.

SUBJECTS AND METHODS: Cross-sectional study was conducted to assess the awareness of the hazards of carbonated drinks among female medical students in King Faisal University in Al-Ahssa, Saudi Arabia. A questionnaire was prepared in English in relation to the knowledge, altitude and practice and was distributed to 50 students.

RESULT: Out of all participants (94\%) had knowledge about ill effect of carbonated drinks

CONCLUSION: Appropriate health education for the students should be incorporated. An additional strategy should implemented by governments to suppress soft drinks' advertisements and raise its sales tax to combat this problem.

\section{KEYWORDS}

Awareness, Hazard, Soft Drinks

\section{INTRODUCTION:}

The term soft drinks refers to non-alcoholic water based flavored drinks that are potentially sweetened, acidulated and carbonated (1). Carbonation, which produces the characteristic effervescence and bubbling, occurs when carbon dioxide is dissolved in water or an aqueous solution. The acidic nature is derived from conversion of dissolved $\mathrm{CO} 2$ to $\mathrm{HCO} 3$ and $\mathrm{H}+$ by interaction with $\mathrm{H} 2 \mathrm{O}$ as well as additives such as citric acid, phosphoric acid (2)and benzoic acid which is commonly used as preservative (3). Sugars, which are added to many carbonated beverages to impact a sweet taste, add calories and increase the osmolality of the beverage. Artificial sweeteners provide a sugary taste without increasing the caloric content of the beverage (2). Also, these drinks contain synthetic coloring and flavoring agents that are allergenic (4). Other additives such as caffeine is also present in cola type of soft drinks and in energy drinks 2 .

Scientific studies have shown how as few as one or two soft drinks a day can increase one's risk for numerous health problems (5). First, soft drinks contain no nutrients and they cause nutritional deficiencies because when one consumes carbonated beverages instead of milk, juice and water, body will not get some of the nourishment as per the needs (6). Second, dental cavities are often associated with carbonated beverage because the amount of sugars that are consumed is important in forming caries, in which a cavity affects only the enamel, the outer protective layer of a tooth. Caries are caused by the bacteria Mutans streptococci that attach to teeth and produce high amounts of acid from sugars and other types of acid. The acids that are not buffered dissolve the apatite crystals of a tooth's surface; this process is called demineralization. Teeth can be mineralized by calcium, fluoride and phosphate, which are all contained in saliva. Carries are formed when the process of demineralization occurs more often than the process of remineralization (6). Another thing is that caffeine is considered as a mildly addictive stimulation drug which can cause disturb sleep patterns, bedwetting and anxiety in children and young adults (7). Also, it is a natural diuretic, and so can actually make thirstier and encourage dehydration (6). Furthermore, it can cause withdrawal symptoms, such as headache, fatigue, decreased alertness, depressed mood and irritability (7) and it can result in extra heartbeats (6). In addition, caffeine has been identified as a risk factor for osteoporosis $(8,9)$. Moreover, soft drink consumption has been found to be associated with low bone mineral density (BMD) and fractures in adolescent girls $(10,11,12)$, although some suggest that such associations may be due to displacement of milk consumption more than to any direct effect of soft drink components (13). Likewise, the phosphoric acid, which was shown to interfere with calcium absorption and to contribute to imbalances that lead to additional loss of calcium $(8,9)$. It has also been suggested that the high fructose corn syrup used to sweeten carbonated beverages may negatively affect bone (14). Additionally, sugar-sweetened beverage consumption may lead to type 2 diabetes because of its effect on weight gain (15), as well as its glycaemic effects, inducing rapid spikes in glucose and insulin and causing insulin resistance $(16,17)$. Furthermore, caffeine and the acids can cause gastronomic distress, which is characterized by increased stomach acid levels and causes the inflammation of the stomach and erosion of the stomach lining resulting in stomachache and disruption of the digestion (6). Last but not least, Dr. Charles Best claims that teenagers who consume too many soft drinks have cirrhosis of the liver similar to what chronic alcoholics have (6)

Although carbonated drinks have lots of hazards, it was found that carbonated drinks are the third most consumed beverage (18), which indicates that they are very popular, especially among youngsters (19). Soft drinks consumption is associated with a number of personal factors including the taste (20) and parental influences (21)and environmental factors such as the availability of soft drinks, especially in the home $(22,23)$, portion size (including the small price differential for larger portions) $(24,25)$ and the level of exposure for marketing (26). Youngsters consume carbonated drinks in breathtaking quantities and are often unaware of the health hazards of the excess consumption (19). So, the present study was conducted with the objective to find out whether the medical students in King Faisal University in Al-Ahsaa have the complete awareness about the hazards of carbonated drinks or not.

\section{SUBJECTS AND METHODS}

Cross-sectional study was conducted to assess the awareness of the hazards of carbonated drinks among female medical students. 50 female medical students were randomly selected with age ranging from 18 to 24 years old(from the first to six year studying students ) in King Faisal University in Al-Ahssa, Saudi Arabia.

For this purpose, a questionnaire consisting of 3 parts was designed. The first section dealt with knowledge of students regarding the carbonated drinks (5 questions) the second section dealt with attitude of the students (2 questions) and the third part was about the practice of the Students regarding the Carbonated Drinks ( 5questions). The questionnaire was distributed to the students to be filled by them. The data were collected and analyzed using software program SPSS version 21 . Frequency and percentage were calculated.

\section{RESULTS:}

Number of students who had participated in present study is 50 female medical students from King Faisal University. Table 1 shows the knowledge of the students regarding carbonated drinks. All the 50 $(100 \%)$ students had ever knew about carbonated drinks. $42(84 \%)$ students know either most of the components or some of them, but 8 $(16 \%)$ students have no idea about the composition of carbonated drinks. It was shown that $40(80 \%)$ of participants know that carbonated drinks contain sugar, 31 (62) know about carbon dioxide (Co2), 29 (58) know about caffeine, 15 (30\%) know about citric acid, 9 $(18 \%)$ know about high fructose corn syrup and $8(16 \%)$ know about phosphoric acid. Most of the participants $42(84 \%)$ know that 
osteoporosis one of the side effects of carbonated drink consumption and the side effect that has the least percentage $7(14 \%)$ is belching. 39 $(78 \%)$ are aware about obesity, $36(72 \%)$ are aware about teeth decay, $24(48 \%)$ are aware about diabetes type 2 and $21(42 \%)$ are aware about gastritis.

Table: 1 Knowledge of the students regarding the carbonated drinks $(\mathrm{n}=\mathbf{5 0})$

\begin{tabular}{|c|c|c|c|}
\hline Responses: & & Frequency & $\%$ \\
\hline \multirow{2}{*}{$\begin{array}{l}\text { Knowing About } \\
\text { Carbonated Drinks }\end{array}$} & Yes & 50 & 100 \\
\hline & No & 0 & \\
\hline \multirow{2}{*}{$\begin{array}{l}\text { Reading the ingredients on } \\
\text { the bottles: }\end{array}$} & Yes & 34 & \\
\hline & No & 16 & \\
\hline \multirow{2}{*}{$\begin{array}{l}\text { knowing about the } \\
\text { composition of carbonated } \\
\text { drinks }\end{array}$} & Yes & 42 & \\
\hline & No & 8 & 16 \\
\hline \multirow{6}{*}{$\begin{array}{l}\text { Knowing that carbonated } \\
\text { drinks contain: }\end{array}$} & Sugar & 40 & \\
\hline & Co2 & 31 & \\
\hline & Caffeine & 29 & \\
\hline & Citric Acid & 15 & 30 \\
\hline & $\begin{array}{l}\text { contain high } \\
\text { fructose corn syrup }\end{array}$ & 9 & 18 \\
\hline & phosphoric acid & 8 & \\
\hline \multirow{9}{*}{$\begin{array}{l}\text { knowing about the side } \\
\text { effects of carbonated drinks }\end{array}$} & Yes & 47 & \\
\hline & No & 3 & 6 \\
\hline & Osteoporosis & 42 & \\
\hline & Obesity & 39 & \\
\hline & Teeth Decay & 36 & \\
\hline & Diabetes Type 2 & 24 & \\
\hline & Gastritis & 21 & \\
\hline & Sleep Disturbance & 10 & \\
\hline & \begin{tabular}{|l|} 
Belching \\
\end{tabular} & 7 & \\
\hline
\end{tabular}

Table: 2 Attitude of the students regarding the carbonated drinks $(\mathrm{n}=\mathbf{5 0})$

\begin{tabular}{|l|l|l|l|}
\hline Responses: & & Frequency & $\%$ \\
\hline \multirow{4}{*}{ What would you like to prefer } & Fruit Juice & 33 & 66 \\
\cline { 2 - 4 } & Carbonated Drinks & 9 & 18 \\
\cline { 2 - 4 } & Water & 5 & 10 \\
\cline { 2 - 4 } & Milk & 3 & 6 \\
\hline \multirow{2}{*}{$\begin{array}{l}\text { Planning to stop carbonated } \\
\text { drinks }\end{array}$} & Yes & 13 & 26 \\
\cline { 2 - 4 } & No & 22 & 44 \\
\cline { 2 - 4 } & I don't know & 7 & 14 \\
\hline
\end{tabular}

Table-3: Practice of students regarding the Carbonated Drinks $(\mathbf{n}=\mathbf{5 0})$

\begin{tabular}{|c|c|c|c|}
\hline Responses: & & Frequency & $\%$ \\
\hline \multirow[t]{3}{*}{ Drinking Carbonated Drinks } & Yes & 33 & 87 \\
\hline & No & 7 & 61 \\
\hline & Already stopped & 3 & 6 \\
\hline \multirow{3}{*}{$\begin{array}{l}\text { Frequency of Drinking } \\
\text { Carbonated Drinks }\end{array}$} & Less-No drinking & 35 & 70 \\
\hline & Sometime Drinking & 5 & 10 \\
\hline & Frequent Drinking & 10 & 20 \\
\hline \multirow{9}{*}{$\begin{array}{l}\text { Reasons to drink carbonated } \\
\text { Drinks }\end{array}$} & Taste & 33 & 66 \\
\hline & Satisfy Thirst & 19 & 38 \\
\hline & Appeal of Drink & 10 & 20 \\
\hline & Feel Energize & 8 & 16 \\
\hline & Easy Access & 7 & 14 \\
\hline & Family Influence & 3 & 6 \\
\hline & \begin{tabular}{|l|} 
Peer Pressure \\
(Friends)
\end{tabular} & 3 & 6 \\
\hline & $\begin{array}{l}\text { Media } \\
\text { Advertisements }\end{array}$ & 3 & 6 \\
\hline & Others & 8 & 16 \\
\hline \multirow{4}{*}{$\begin{array}{l}\text { Number of years drinking } \\
\text { carbonated drinks }\end{array}$} & $4-6$ & 2 & 4 \\
\hline & $7-9$ & 8 & 6 \\
\hline & $10-12$ & 17 & 34 \\
\hline & $12-15$ & 9 & 18 \\
\hline
\end{tabular}

\begin{tabular}{|l|l|l|l|}
\hline & More than 15 & 6 & 12 \\
\hline Favorite Carbonated Drink & Pepsi & 21 & 42 \\
\cline { 2 - 4 } & Cola & 7 & 14 \\
\cline { 2 - 4 } & $7 \mathrm{Up}$ & 6 & 12 \\
\cline { 2 - 4 } & Shani & 3 & 6 \\
\hline & Mirinda & 3 & 6 \\
\hline & Cade & 1 & 2 \\
\hline & Beer & 1 & 2 \\
\hline
\end{tabular}

Table: 2 Depicts attitude of students regarding consumption of the carbonated drinks. Around 33 (66\%) participants prefer to drink fruit juice instead of carbonated drinks, $9(18 \%)$ participants prefer to drink carbonated drinks, $3(6 \%)$ participants prefer milk and $5(10 \%)$ water is their favorite drink. However about $22(44 \%)$ participants responded that they never had tried or thought to stop drinking carbonated drinks, 13 (26\%) participants are planning to stop drinking carbonated drinks and $7(14 \%)$ participants had no idea

Table 3 shows the practice of students regarding consumption of carbonated drinks. There were $8(16 \%)$ students who did not drink carbonated drinks at all and 3(6\%) students who already stopped drinking carbonated drinks ,but there were $39(78 \%)$ participants who still drink carbonated drinks . regarding practice of a frequent consumption, $10(20 \%)$ participants were those who consumed carbonated drinks frequently and $5(10 \%)$ students had responded that they sometimes consumed carbonated drinks and $35(70 \%)$ students who rarely or never drink carbonated drinks. 33(66\%) students considered taste as the main influencing factor for the consumption of carbonated drinks and 19(38\%) participants considered that the main cause of their consumption of carbonated drinks is to satisfy Thirst and $10(20 \%)$ students drink carbonated drinks because of the appeal of drinking and $8(16 \%)$ participants drink carbonated drinks because they make them feel energize and that followed by easy access $7(14 \%)$ and Media Advertisement 3(6\%), Family influence3(6\%), Peer Pressure (Friends) 3 (6\%).However, there were 8 (16\%) participants who drink carbonated drinks for other reasons.

Pepsi 21(42\%) was the main brand of carbonated drinks that was consumed commonly followed by Cola $7(14 \%)$, 7Up $6(12 \%)$, Mirinda 3(6\%), Shani $3(6 \%)$, Cade1 $(2 \%)$ and Beer $1(2 \%)$. The study also shows the number of years of drinking carbonated drinks, there were $17(34 \%)$ students who have drunk carbonated drinks for 10-12 years and $9(18 \%)$ participants who have drunk carbonated drinks for $12-15$ years and $6(12 \%)$ students have consumed carbonated drinks more than 15 years while 8

$(6 \%)$ students who have consumed carbonated drinks for 7-9 years and just 2(4\%) participants who have drunk carbonated drinks for 4-6 years.

\section{DISCUSSION:}

The present study revealed that that all the students (100\%) who had participated in this study have heard about carbonated drinks. This finding is similar to what was reported by Kharde A, et.al. (18).

In the present study, it was found that more than two-thirds (78\%) of medical students drink carbonated drinks this value is comparable to high consumption of carbonated drinks of high school students of united states which was about two-thirds (65\%) (27), but it is considered to be higher than US children and youth from 6 to 17 years of age which was found to be increased from $37 \%$ to $56 \%$ (28). Furthermore, in the present study it was found that the students were highly aware about side effects of carbonated drinks (94\%) which is comparable to other studies $(6,18)$. Moreover, the students were more aware about individual side effects as obesity (78\%), osteoporosis $(84 \%)$ and teeth decay $(72 \%)$ This is in controversy to the other study which revealed that only $28.2 \%$ of the participants identified the obesity as a side effect, $11 \%$ for osteoporosis and only $9.1 \%$ for teeth decay (18). Regarding this study, it was found that only $20 \%$ of them consume carbonated drinks frequently. This is in controversy to results of Kharde et al.,(18) which revealed that $(50 \%)$ of the participants frequently drink carbonated drinks and the results of Wilson E D et al which stated that over half of the boys and more than one third

of the girls reported drinking soft drink daily among adolescents in Australia(29). Moreover, The majority of the participants about $34 \%$ have started drinking 10 to 12 years ago which is long period 
compared to other study which showed that more than $50 \%$ of the participants have started to drink for less than 10 years. Kharde et al.,(18). Generally, $84 \%$ of the participants knew at least one of the composition of carbonated drinks. Most of them know that they contain sugar $(80 \%), \mathrm{Co} 2(60 \%)$ and caffeine $(58 \%)$ but only (18\%) had knowledge that soft drinks contain high fructose corn syrup. it was found that Despite fructose and glucose have very similar chemical structure, they are absorbed and metabolized by completely different pathways. Fructose is absorbed through the GLUT-5 receptor in the gut (30), and in contrast to glucose, is metabolized almost entirely in the liver by a pathway that is not dependent on insulin (31). Accordingly, there is evidence to show that fructose consumption does not stimulate insulin secretion or leptin production by adipose tissue (32-33) and thereby is thought to contribute more directly to weight gain (33). Also, excess fructose consumption has been shown to be more related to the specific accumulation of visceral fat and associated metabolic risk factors, such as insulin resistance, than is excess glucose consumption (34). Fructose consumption has also been shown to have a potential negative impact on cardiovascular health: for example, as compared to glucose, fructose consumption has been shown to prompt an acute rise in blood pressure (35) and in triglyceride synthesis $(32,33$, and 36). Moreover, only $16 \%$ of the students were aware about phosphoric acid which is an important determinant of mortality in patients with chronic kidney disease (37). In addition, our study revealed that Pepsi (42\%) was the main brand of carbonated drinks that was consumed commonly followed by Cola (14\%). Previous studies referred to a common problem that is associated with consumption of a large number of carbonated drinks which is increased acid levels throughout the body. All soft drinks are very acidic, but dark colas such as Coke and Pepsi are much more acidic (5). The findings of the present study indicated that the main reason $(66 \%)$ for carbonated drink consumption by students is enjoying the taste of these drinks. This is consistent with a study by Mahmood et al, who declared that female young adults reported enjoying the taste of soft drinks as the main reason $(32 \%)$ for using them (38). Grimm et al reported that most students $(96 \%)$ used soft drinks as a result of the inclination to taste carbonated drinks. According to them, individuals with a strong taste for carbonated drinks are 4.5 times more likely to use them during the week (39). Madani et al reported that the major reasons for drinking carbonated drinks by female students of Jaddeh to be enjoying the taste of drinks, parents' habit for drink consumption, and presence of carbonated drinks at home (40). Also, the study revealed that about $44 \%$ of the students will not stop soft drinks and about $14 \%$ do not know if they will stop or not and only $6 \%$ who already stopped drinking. This is coincides with de Bruin and colleagues who have reported a negative correlation between soft drink consumption and the attitude towards a limited soft drink intake (41)

\section{CONCLUSION:}

Carbonated drinks consumption is a growing phenomenon affecting all age groups in our community especially the adolescents which is associated with lots of health effects ranging from obesity to tooth and bone problems. In the present study, although the knowledge of participants regarding carbonated drinks were satisfactory. The attitudes of the students had some controversy because most of them had not tried to or planned to stop this habit which is hard to be changed by carbonated drinks consumers because they find it delicious although they were ready to consume fruit juice as an alternative for carbonated drinks if an option is available. Regarding practice, most of them had started to drink carbonated drinks at a very early age of life and this is a main concern. In order to diminish use of carbonated drinks by students, it is necessary to provide appropriate training for the students and their parents about the adverse effects of carbonated drinks, as well as to lower the price and improve access to healthy drinks such as natural fruit juice, mineral water, and low-fat milk. Additional strategies which may be implemented by governments is to suppress advertisements encouraging soft drink use, produce and promote flavored milks, increase the number of hygienic water dispensers in the streets. Moreover, more research needs to be done with larger sample sizes and broader age range to proof the association with different health effects.

\section{REFERENCES:}

Mathur HB, Johnson S, Kumar A. A report on Analysis of Pesticide Residues in Soft drinks. New Delhi, India: Center for Science and Environment Pollution Monitoring Laboratory; 2003 Aug 5 .

2. Johnson T, Gerson L, et al. Systematic review: the effects of carbonated beverages on gastrooesophageal reflux disease. Aliment Pharmacol Ther 2010;31:607-614. Ofori H, Owusu M \&Anyebuno G. Heavy Metal Analysis of Fruit Juice and Soft Drinks
Bought 4.From Retail Market in Accra, Ghana. Journal of Scientific Research \& Reports 2013;2(1): 423-428

4. Patil, S.R, Kurhekar, S.P. and Patil, R.R. Study on development of custard apple carbonated beverage, Internat. J. Proc. \& Post Harvest Technol 2011;2(1):56-58.

Nylund J. The Harmful Effects of Soft Drinks. North Lake College: 2002

6. Kishore S, Aggarwal P \&Muzammil K. KAP Study About Carbonated Drinks Among Medical and Nursing Students at Teaching Hospital. JK Science Journal of Medical Education and Research 2009; 11(4): 196- 199

Juliano LM, Griffiths RR. A critical review of caffeine withdrawal: empirical validation of symptoms and signs, incidence, severity, and associated features. Psychopharmacology (Berl) 2004; 176(1): 1-29.

8. Rapuri PB, Gallagher JC, Kinyamu HK, Ryschon KL. Caffeine intake increases the rate of bone loss in elderly women and interacts with vitamin D receptor genotypes. Am J ClinNutr 2001; 74: 694-700.

9. Tucker KL, Morita K, Qiao N, et al. Colas, but not other carbonated beverages, are associated with low bone mineral density in older women: The Framingham Osteoporosis Study. Am J ClinNutr 2006; 84: 936-42.

10. Wyshak G. Teenage girls, carbonated beverage consumption, and bone fractures. Arch Pediatr Adolesc Med 2000; 154: 610-613.

11. McGartland C, Robson PJ, Murray L, et al. Carbonated soft drink consumption and bone mineral density in adolescence: the Northern Ireland Young Hearts project. J Bone Miner Res 2003; 18: 1563-9.

12. Whiting SJ, Healey A, Psiuk S, Mirwald R, Kowalski K, Bailey DA. Relationship between carbonated and other low nutrient dense beverages and bone mineral content of adolescents. Nutr Res 2001;21:1107-15.

13. Fitzpatrick L, Heaney RP. Got soda? J Bone Miner Res 2003; 18(9): 1570-2.

14. Milne DB, Nielsen FH. The interaction between dietary fructose and magnesium adversely affects macromineral homeostasis in men. J Am Coll Nutr 2000; 19:31-7

15. Malik VS, Schulze MB, Hu FB. Intake of sugar-sweetened beverages and weight gain: a systematic review. Am J Clin Nutr 2006; 84: 274-288.

16. Hu FB, Malik VS. Sugar-sweetened beverages and risk of obesity and type 2 diabetes: epidemiologic evidence. Physiol Behav 2010; 100: 47-54

17. Malik VS, Hu FB. Sweeteners and risk of obesity and type 2 diabetes: the role of Mugarsweetened beverages. Curr Diabetes Rep 2012;12:195-203.

18. Kharde AL, Deshpande JD, Phalke DB. Knowledge, attitude and practices (KAP) regarding carbonated drinks among students of medical college of western Maharashtra. Int J Med Sci Public Health. 2013; 2(4): 912-915.

19. Gour N, Srivastava D, Adhikari P. Study to assess the Prevalence of Soft Drinking and its Determinants among the School going Children of Gwalior city. Online J health Allied Scs. $2010 ; 9(2): 5$

20. May J, Waterhouse PJ. Dental erosions and soft drinks: a qualitative assessment of knowledge, attitude and behavior using focus groups of schoolchildren. A preliminary study. Int J Paediatr Dent 2003;13(6): 425-33.

21. Vereeckn CA, Keukelier E, Maes L. Influence of mother's educational level on food parenting practices and food habits of young children. Appetite 2004; 43(1): 93-103.

22. Grimm GC, Harnack L, Story M. Factors associated with soft drink consumption in school-aged children. JAm Diet Assoc 2004; 104: 1244- 1249.

23. Kassem NO, Lee JW. Understanding soft drink consumption among male adolescent using the theory of planned behavior. J Behav Med 2004; 27(3): 273-96.

24. Flood JE, Roe LS, Rolls BJ. The effect of increased beverage portion size on energy intake at a meal. J Am Diet Assoc 2006; 106(12): 1984-90.

25. Rolls BJ, Roe LS, Meengs JS. The effect of large portion sizes on energy intake is sustained for 11 days. Obesity (Silver Spring) 2007; 15(6): 1535-43.

26. James P, Finer N, Lobestin T, Baillie K, Leach RJ, Scarrott F et al. Obesity in Europe The case for action. London, European Association of the study of obesity, 2002.

27. Park S, Blanck H M, Sherry B, Brener N, Toole TO. Factors Associated with SugarSweetened Beverage Intake among United States High School Students. The Journal of Nutrition 2012. doi: 10.3945/jn.111.148536.

28. Park S, Sherry B, Foti K, Blanck HM. Self-reported academic grades and other correlates of sugar-sweetened soda intake among U.S. adolescents. Journal of the Academy of Nutrition and Dietetics. 2012;112:125-31.

29. Denney-Wilson, E., Crawford, D., Dobbins, T., Hardy, L. \& Okely, A. D. (2009) Influences on consumption of soft drinks and fast foods in adolescents. Asia Pacific Journal of Clinical Nutrition, 18 (3), 447-452.

30. Stanhope KL, Schwarz JM, Keim NL et al. Consuming fructose-sweetened, no glucosesweetened, beverages increases visceral adiposity and lipids and decreases insulin sensitivity in overweight/obese humans. J Clin Invest 2009;119:1322-1334.

31. Douard V, Ferraris RP. Regulation of the fructose transporter GLUT5 in health and disease. Am J Physiol Endocrinol Metab 2008;295: E227-E237.

32. Gaby AR. Adverse effects of dietary fructose. Altern Med Rev 2005;10: 294-306.

33. Teff KL, Grudziak J, Townsend RR et al. Endocrine and metabolic effects of consuming fructose- and glucose-sweetened beverages with meals in obese men and women: influence of insulin resistance on plasma triglyceride responses. J Clin Endocrinol Metab 2009;94:1562-1569.

34. Stanhope KL, Havel PJ. Endocrine and metabolic effects of consuming beverages sweetened with fructose, glucose, sucrose, or high-fructose corn syrup. Am J Clin Nut 2008;88:1733S-1737S

35. Brown CM, Dulloo AG, Yepuri G, Montani JP. Fructose ingestion acutely elevates blood pressure in healthy young humans. Am J Physiol Regul Integr Comp Physio 2008;294:R730-R737.

36. Parks EJ, Skokan LE, Timlin MT, Dingfelder CS. Dietary sugars stimulate fatty acid synthesis in adults. J Nutr 2008;138:1039-1046.

37. Shutto Y, Shimada M, Kitajima M, Yamabe H, Razzaque MS (2011) Lack of Awarenes among Future Medical Professionals about the Risk of Consuming Hidden PhosphateContaining Processed Food and Drinks. PLoS ONE 6(12): e29105. doi:10.1371/journal.pone.0029105

38. Mahmood M, Saleh A, Al-Alawi F, et al. Health effects of soda drinking in adolescen girl in the United Arab Emirates. J Crit Care 2008; 23(3): 434-50.

39. Grimm G, Harnak L, Story M. Factors associated with soft drink consumption in schoolaged children. J Am Diet Assoc 2004; 104(8): 1244-9.

40. Madani KA, Jambi HA, Bin Sadiq BA, et al. Factors associated with soft drink consumption in school-aged girls in Saudi Arabia. Int J Food Safety Nutr Public Health 2008; 1(2): 150-8.

41. de Bruijn G-J, Kremers SPJ, de Vries H, van Mechelen W, Brug J. Associations of socialenvironmental and individuallevel factors with adolescent soft drink consumption: results from the SMILE study. Health Education. 